\title{
MONITORING KINERJA PEGAWAI BIDANG LALU LINTAS DINAS PERHUBUNGAN KABUPATEN LOMBOK TENGAH BERBASIS ANDROID
}

\author{
Romzi $^{1}$, Wire Bagye ${ }^{2}$,Ahmad Tantoni ${ }^{3}$, Hairul Fahmi ${ }^{4}$ \\ 1,2 3,4 Program Studi Teknik Informatika, STMIK Lombok \\ Jln. Basuki Rahmat No.105 Praya Lombok Tengah 83511

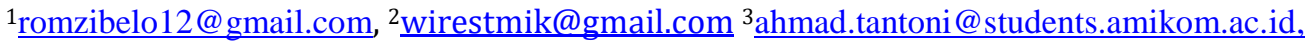 \\ 4iroel.ami@gmail.com
}

\begin{abstract}
The Central Lombok District Transportation Service Office is a regional government implementer in the transportation sector led by the Head of the Service and responsible to the District Head through the Regional Secretary. The problem that often occurs in the Department of Transportation is employees who are not disciplined when discussing in the field of traffic. This is due to lack of direct monitoring from the leadership. When the schedule for carrying out field assignments, there are several employees who are not in the place where the employee is assigned without the knowledge of the leader.

An application is built for employees in the field. This application uses Google Maps API and GPS on Android-based phones. SWOT was used to carry out the analysis in this study. This application will send a list of selected locations via the employee's smartphone. The results of this study are applications that can help the Head of Field to monitor the location of employees using an Android smartphone.
\end{abstract}

Keywords: Monitoring, Android, Gps, Google Maps, Longitude, Latitude

\begin{abstract}
Abstrak
Kantor Dinas Perhubungan Kabupaten Lombok Tengah merupakan pelaksana pemerintah daerah di bidang perhubungan yang dipimpin oleh Kepala Dinas dan bertanggung jawab kepada Bupati melalui Sekretaris Daerah. Masalah yang sering terjadi di Dinas Perhubungan adalah pegawai yang tidak disiplin saat bertugas di bidang lalu lintas. Hal ini disebabkan oleh monitoring langsung dari pimpinan yang kurang. Saat jadwal melaksanakan tugas lapangan, ada beberapa pegawai yang tidak berada di tempat pegawai tersebut di tugaskan tanpa sepengetahuan pimpinan.

Dibangun sebuah aplikasi monitoring khusus untuk pegawai yang bertugas di lapangan. Aplikasi ini memanfaatkan Google Maps API dan GPS yang ada pada ponsel berbasis Android. SWOT digunakan untuk melakukan analisa dalam penelitian ini. Aplikasi ini akan mengirim koordiant lokasi keberadaan pegawai melalui smartphone milik pegawai tersebut. Hasil dari penelitian ini adalah adanya aplikasi yang dapat membantu Kepala Bidang untuk melakukan monitoring lokasi pegawai dengan memanfaatkan smartphone android.
\end{abstract}

Kata kunci : Monitoring, Android, Gps, Google Maps, Longitude, Latitude

\section{PENDAHULUAN}

Dinas Perhubungan Kabupaten Lombok Tengah merupakan unsur pelaksana pemerintah daerah di bidang perhubungan yang dipimpin oleh kepala dinas dan bertanggung jawab kepada bupati melalui sekretaris daerah. Dinas Perhubungan terdapat beberapa bidang yang bekerja untuk melayani pemerintah daerah yang ada di Lombok Tengah salah satunya adalah bidang lalu lintas yang dimana tugas dari bidang lalu lintas di Dinas Perhubungan adalah 
penyelenggaraan kebijakan lalu lintas meliputi urusan manajemen lalu lintas, rekayasa lalu lintas serta sarana dan prasarana lalu lintas.

Masalah yang terjadi dalam bidang lalu lintas Dinas Perhubungan adalah kurang disiplinya pegawai yang sedang melaksanakan tugas lapangan karena tidak adanya monitoring langsung dari Kepala bidang. Dalam melaksanakan tugas, beberapa pegawai yang tidak menghadiri lokasi dimana pegawai tersebut di tugaskan tanapa sepengetahuan Kepala bidang.

Untuk meningkatkan kedisiplinan kinerja pegawai bidang lalu lintas di Dinas Perhubungan Lombok Tengah, monitoring langsung oleh pimpinan sangat penting untuk kelangsungan kinerja pegawai agar tidak ada yang melanggar aturan yang di terapkan di kantor terutama di bidang lalu lintas. Maka dari itu dibutuhkan aplikasi yang dapat membantu Kepala bidang memonitoring kinerja pegawai yang sedang melaksanakan tugas di lapangan apakah sudah sesuai dengan Surat Perintah Tugas ( SPT ) yang di tetapkan.

\section{TINJAUAN PUSTAKA}

Utama dkk tahun (2016) dalam penelitiannya yang bertema aplikasi pemantau lokasi keberadaan anak yang menggunakan LBS (Location Based Service) dan metode yang digunakan adalah metode penelitian SDLC (Software Development Life Cycle) dengan teknik waterfall. Hasil yang di dapatkan dari penelitiannya adalah adanya aplikasi yang dapat membantu para orang tua untuk mengawasi keberadaan anak diluar rumah dengan mudah.

Suwandi tahun 2016 dalam penelitiannya yang bertema pemantauan kinerja sales dengan memanfaatkan Monitoring Geofencing. Hasil dari penelitiannya adalah mampu membuat aplikasi yang dapat membantu kinerja untuk pengawasan sales yang sedang bertugas dilapangan.

Wihidayat, Rahmanto, Doewes tahun (2015) dalam penelitiannya yang berjudul mobile positioning menggunakan network identity sebagai sistem absensi berbasis mobile menggunakan metode Prototyping. Hasil yang didapatkan dari penelitiannya adalah menunjukkan Mobile Positioning yang menggunakan kombinasi Cell Id dan Wi-fi memiliki kepresisian yang cukup untuk proses validasi bahwa karyawan UNS sudah berada di area kerja.
Handaya tahun (2017) dalam penelitiannya yang berjudul perancangan sistem pemantauan kinerja dan lokasi kendaraan bagian pelayanan pelanggan dan hasilnya adalah memberikan kemudahan kepada pelanggan untuk melapor kerusakan dan melaporkan kinerja petugas yang berada dilapangan.

Anwar dkk tahun (2014) dalam penelitiannya yang bertema pengimplementasian LBS berbasis android untuk mengetahui posisi user menggunakan metode Advanced Positioning. Hasil yang didapatkan dari penelitiannya tersebut adalah tersedianya aplikasi yang memberikan informasi seputar keberadaan user.

\section{METODE PENELITIAN}

Metode Analisa yang digunakan adalah analisi SWOT. Analisis SWOT adalah proses identifikasi berbagai faktor secara sistematis guna menentukan rumusan yang tepat dan melakukan strategi perusahaan yang terbaik. Analisis ini berdasarkan pada logika yang dapat memaksimalkan kekuatan (Strengths) dan peluang (Opportunities), namun secara bersamaan dapat meminimalkan kelemahan(Weaknesses) dan ancaman (Threats). Ranguti (2009).

\section{A. Alur Penelitian}

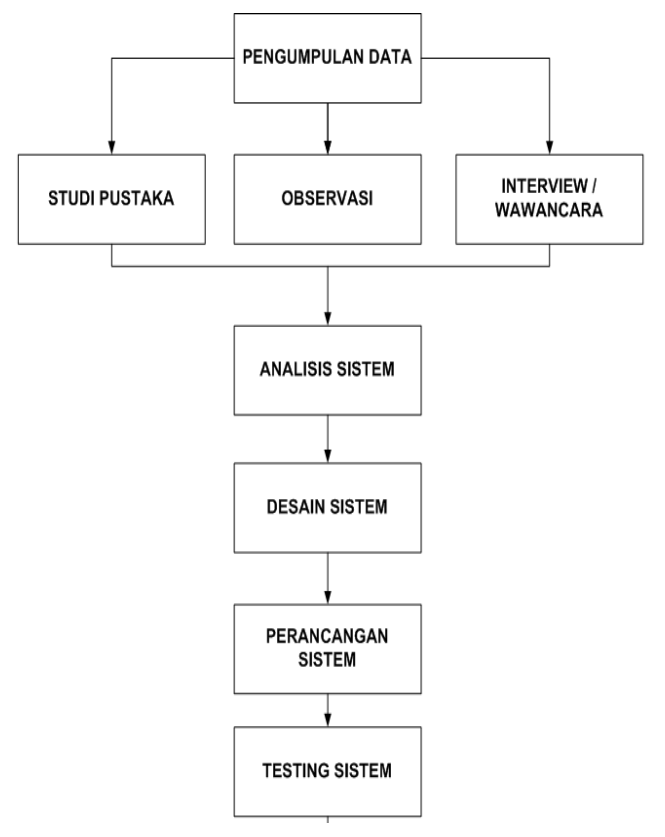

Gambar 1 Alur Penelitian 
a. Pengumpulan data

Adapun metode pengumpulan data dilakukan yaitu sebagai berikut:

1. Studi pustaka yaitu proses pengumpulan data yang dilakukan dengan cara membaca beberapa referensi dari berbagai sumber seperti buku, jurnal, artikel - artikel yang terkait.

2. Wawancara yang dilakukan dengan cara menanyakan langsung kepada narasumber mengenai data atau informasi yang ingin didapatkan.

3. Observasi yang dilakukan dengan cara mengamati lokasi daerah yang sering terjadinya masalah tidak hadirnya pegawai dilapangan.

b. Analisis Sistem

Dalam penelitian ini metode analisa yang digunakan yaitu metode Analisis SWOT untuk mendapatkan informasi dari analisis situasi dan memisahkannya dalam pokok persoalan internal (kekuatan dan kelemahan) dan pokok persoalan eksternal (peluang dan ancaman).

c. Desain Sistem

Setelah dilakukannya proses analisa sistem, pada tahap ini peneliti melakukan proses desain sistem mulai dari proses desain database, relasi antar tabel, dan desain interface untuk aplikasi yang akan di kembangkan.

d. Perancangan Sistem

Pada tahap ini peneliti melakukan proses pengerjaan aplikasi sesuai dengan tahap desain yang sebelumnya dilakukan mulai dari memasukan data - data yang di dapatkan ke dalam database yang selanjutnya di ikuti dalam proses menulis kode atau alogritma program yang telah di tentukan pada proses analisa sistem sebelumnya.

e. Testing Sistem

Pada tahap ini, peneliti melakukan proses testing terhadap aplikasi yang sudah dibuat sebelum di implementasikan ke pengguna. Pada tahap testing, peneliti melakukan pengujian dalam segi fungsionnalitas dari aplikasi tersebut

\section{HASIL DAN PEMBAHASAN}

Dari berapa solusi yang ditawarkan, peneliti memilih untuk membuat sebuah sistem monitoring mengguanakan perangkat android, sehingga kinerje pegawai di lapangan lebih disiplin dalam melaksanakan tugasnya.

\section{A. Flowmaps Sistem}

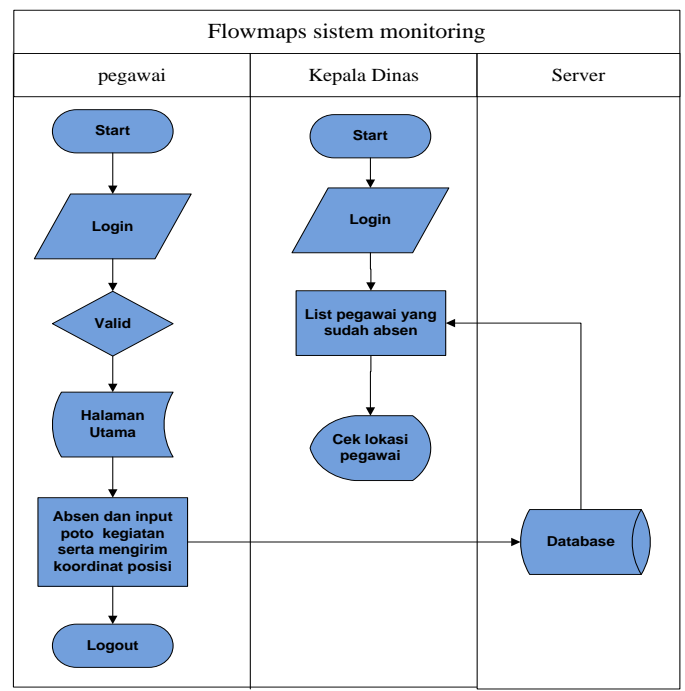

Gambar 4.2 Flowmaps sitem Monitoring

\section{B. Activity Diagram}

Gambar dibawah ini menjelaskan activity menampilkan poisisi pegawai pada peta secara bersamaan pada perangkat android kepala dinas dan menampilkan menu pengiriman laporan dari setiap pegawai.

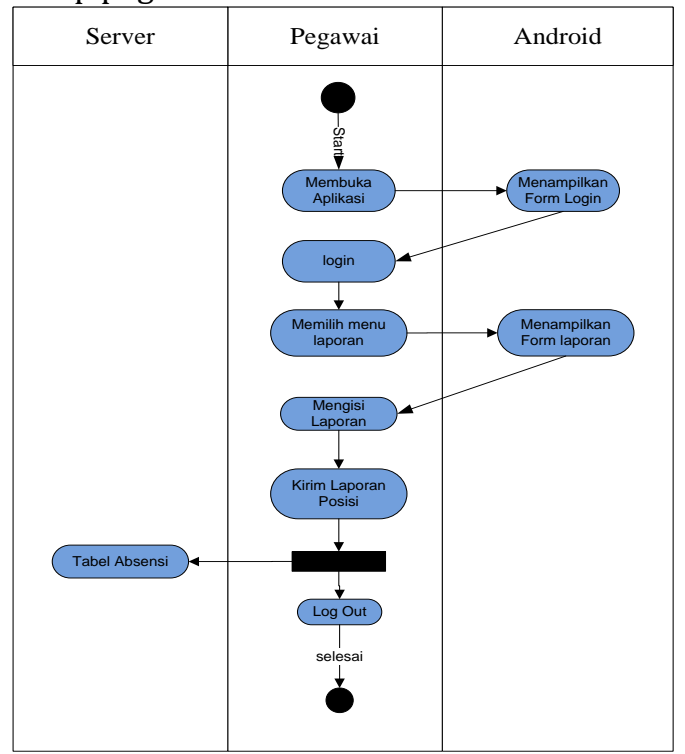

Gambar 4.3 Activity mengirim posisi 


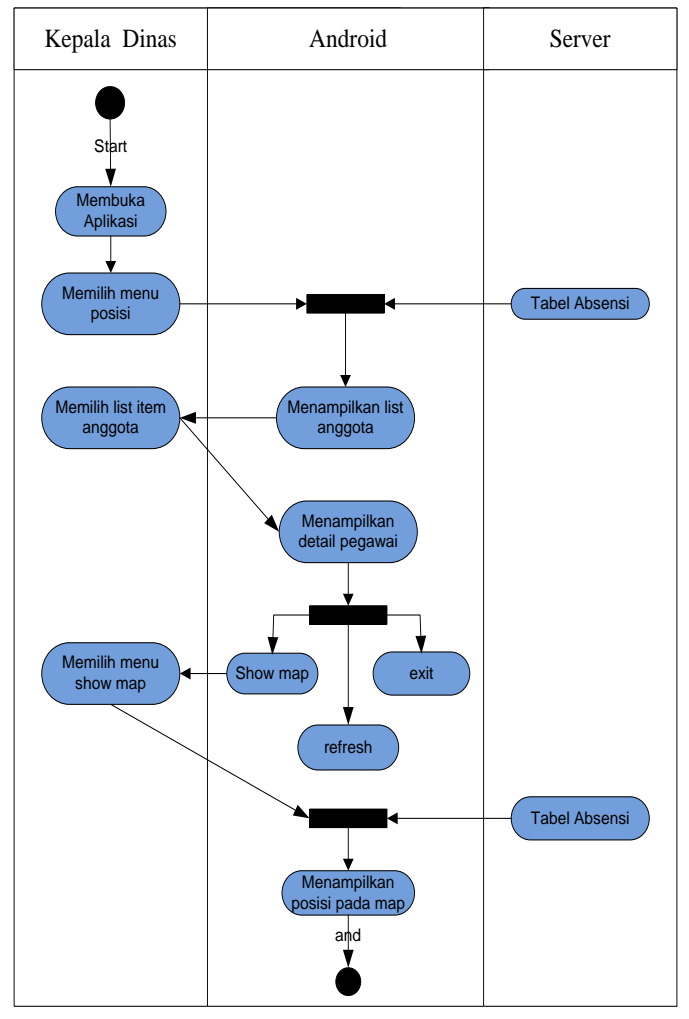

Gambar 4.4 Activity menampilkan posisi

\section{Class Diagram}

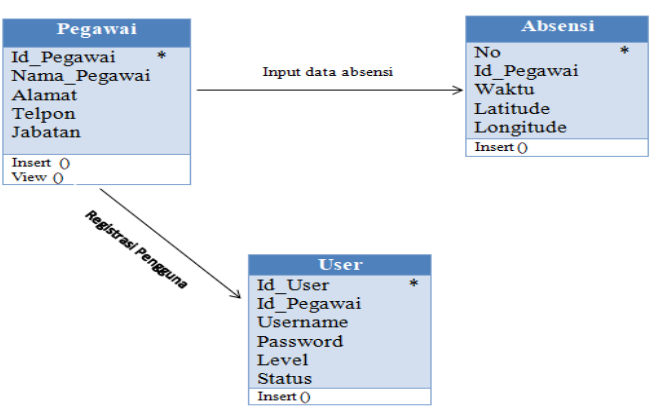

Gambar 4.5 Class Diagram

\subsection{Interface}

Interface adalah salah satu layanan yang disediakan oleh sistem operasi sebagai sarana interaksi antara pengguna dengan sistem informasi. Berikut beberapa interface yang dirancang oleh penulis dan fungsi dari interface tersebut akan dijelaskan secara rinci oleh penulis.

\section{Interface Pegawai}

\section{Halaman Login}

Pada tampilan awal aplikasi monitoring akan ditampilkan halaman login. Halaman ini adalah halaman yang pertama kali yang akan di lihat pegawai ketika membuka aplikasi. Berikut tampilan untuk halaman login pada aplikasi monitoring dapat dilihat pada gambar 4.6.

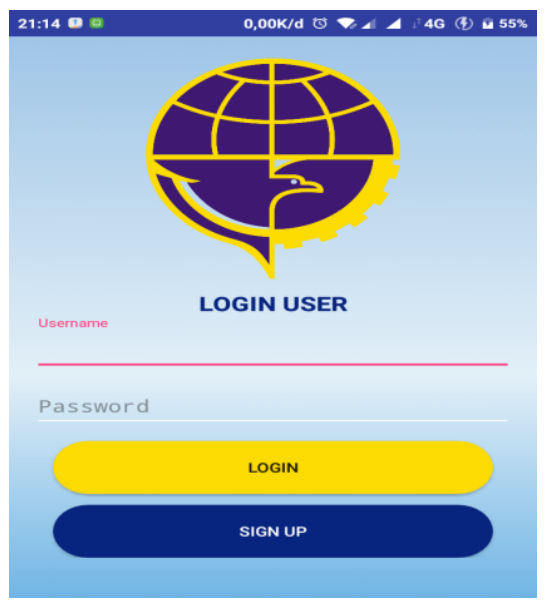

Gambar 4.6 Halaman Login

\section{Menu Utama Pegawai}

Halaman ini berfungsi untuk menampilkan halaman utama dari program ketika pegawai melakukan login dan membuka Aplikasi Monitoring. Interface Halaman Utama Pegawai dapat dilihat pada gambar 4.7.

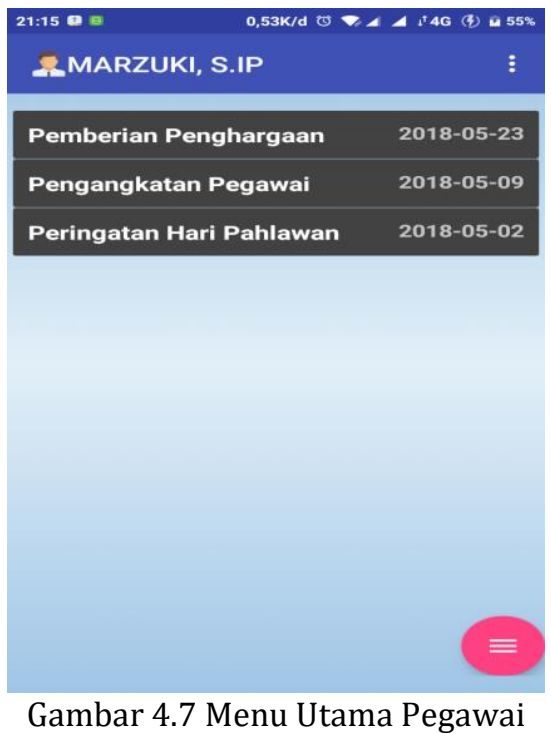

3. Menu Absen Pegawai

Halaman ini adalah halaman untuk setiap pegawai melakukan absensi harian. Dalam halaman ini pegawai dapat melakukan 
pengambilan gambar kegiatan, pengambilan titik koordinat lokasi penjagaan yang akan dikirimkan ke server untuk di monitoring oleh kepala bidang. Interface Halaman Absensi Pegawai dapat dilihat pada gambar 4.8.

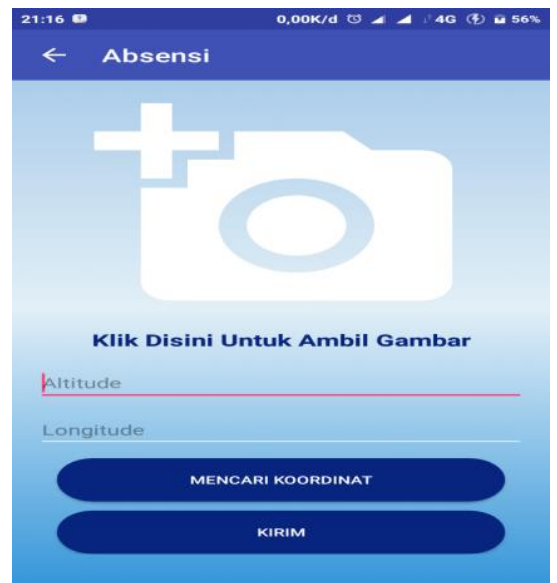

Gambar 4.8. Halaman Absensi Pegawai

\section{E. Interface Kepala Bidang}

\section{Halaman Utama Kepala Bidang}

Halaman ini adalah tampilan halaman utama untuk bagian kepala bidang. Dalam halaman tersebut terdapat sub menu yaitu floating action Button yang berfungsi untuk melihat data pegawai yang sudah melakukan absensi. Interface Kepala Bidang dapat di lihat pada gambar 4.9.

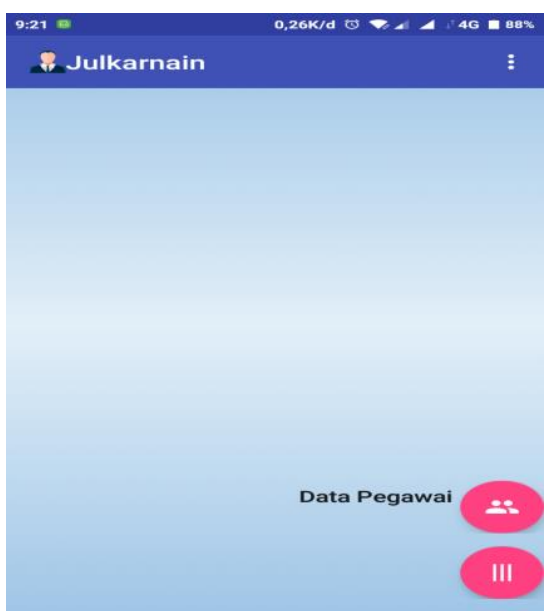

Gambar 4.9 Halaman Utama Kepala Bidang

2. Halaman Data Pegawai

Dalam Halaman ini akan di tampilkan datadata pegawai yang sudah melakukan registrasi dan absensi harian. Interface untuk halaman data pegawai dapat dilihat pada gambar 4.10.

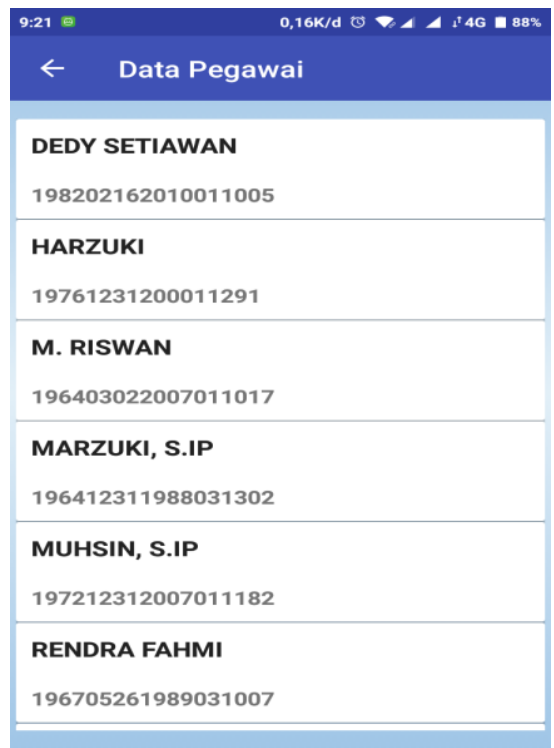

Gambar 4.10 Halaman Data Pegawai

\section{Halaman Detail Absensi}

Halaman ini adalah halaman untuk menampilkan tanggal absensi dilakukan dan letak koordinat yang di kirimkan oleh pegawai. Interface untuk halaman detail absensi pegawai dapat dilihat pada gambar 4.11.

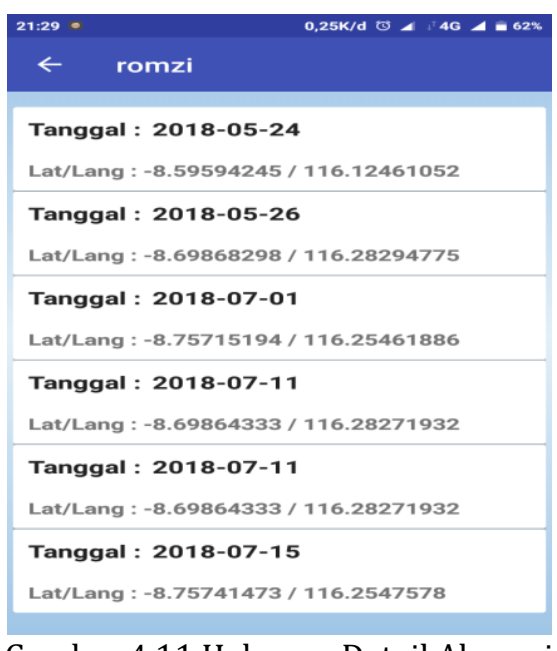

4. Halaman Monitoring Kepala Bagian

Pada halaman ini kepala bidang dapat memonitoring lokasi keberadaan pegawai yang sudah melakukan absensi harian. Interface untuk halaman Monitoring kepala bagian dapat dilihat pada gambar 4.12. 


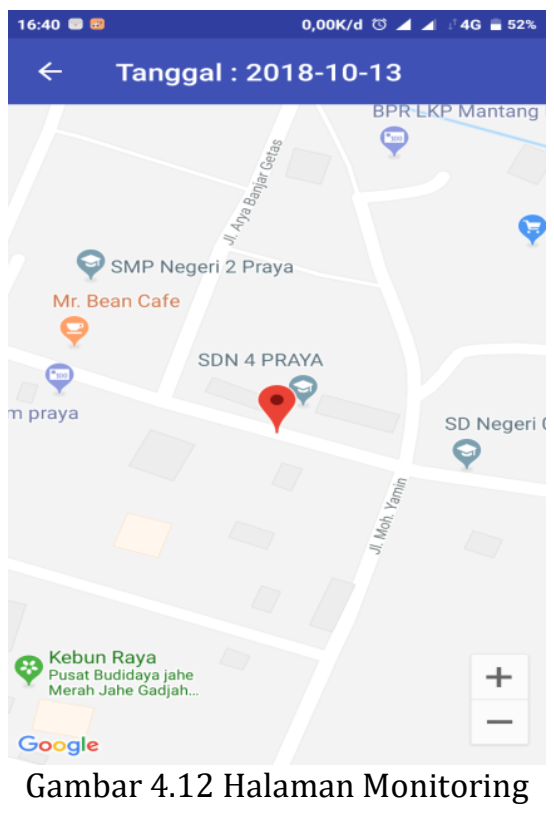

\section{KESIMPULAN DAN SARAN}

\section{A. Kesimpulan}

Berdasarkan uraian pada bagian sebelumnya maka dapat ditarik beberapa kesimpulan mengenai hasil dari implementasi dan pengujian aplikasi Monitoring Kinerja Pegawai Bidang Lalu Lintas Dinas Perhubungan Kabupaten Lombok Tengah sebagai solusi atas permasalahan yang ada, yaitu:

1. Aplikasi yang dibuat mampu membantu kepada bidang memantau lokasi dimana staf sedang ditugaskan.

2. Aplikasi yang dibuat mampu membantu staf melakukan absensi harian dengan mudah melalui smartphone.

3. Hasil uji aplikasi menetukan adanya kekurangan, yaitu dalam mendapatkan titik koordinat dan mencari titik koordinat, user memerlukan adanya koneksi internet. Apabila koneksi internet kurang baik, titik koordinat akan lebih lama untuk didapatkan.

\section{B. Saran}

Berdasarkan penelitian ini penulis memberikan saran untuk pengembang selanjudnya agar dibuatkan system pada sisi wab dan menampilkan titik koordinat disisi wab.
Selanjudnya menambahkan form untuk menampilkan gambar kegiatan staf dilapangan.

\section{Daftar Pustaka:}

[1] Suwandi. Sistem Informasi Pemantaua Kinerja Sales Memanfaatkan Monitoring Geofencing dan Teknologi Cloud Message Berbasis Mobile. Volume 04/Nomor 01/Tahun 2016.

[2] Anwar, Jaya, Kusuma. 2014. Implementasi Location Based Service Berbasis Android Untuk Mengetahui Posisi User. Vol. 13, No. 2, Mei 2014.

[3] Wihidayat,S.T.,M.Eng, Rahmanto, dan Doewes S.Kom., M.Sc. Mobile Positioning Menggunakan Network Identity Sebagai Sistem Absensi Berbasis Mobile. Vol 4. No 2. Desember 2015.

[4] Hidayat. Rancang Bangun Mobile Phone Positioning System Pada Platform Adroid, November 2013.

[5] Growth from Knowledge, 2015. Android Opera Dominasi Smartphone Indonesia. http://id.techinasia.com/android operadominasi- smartphone-indonesia 2014/ (10 April 2018).

[6] Utama, Nurhayati, dan Windasari. Pembuatan Aplikasi Memantau Lokasi Anak Berbasis Android Menggunakan Location Based Service. Vol.4, No.1, Januari 2016.

[7] Neforawati, Fareza dan Juniarti. Rancang Bangun Aplikasi Sistem Informasi Monitoring Absensi Mahasiswa Politeknik Negri Jakarta Menggunakan Teknologi NFC Pada Android. Politeknologi Vol. 14 No. 2 MEI 2015.

[8] Bagye, W., \& Yuliana, Y. (2018). Implementasi Greenfoot 3.0. 4 Untuk Membangun Aplikasi Pengucapan Bahasa Inggris Pada Arrobbany Course. Jurnal Informatika dan Rekayasa Elektronik, 1(1), 25-32.

[9] Bagye, W., \& Najamudin, N. (2018). APLIKASI PENGHITUNG JUMLAH PAKAN SAPI POTONG BERBASIS ANDROID. Jurnal Informatika dan Rekayasa Elektronik, 1(2), 40-46. 